\title{
A Comparison of Social Media Marketing Between B2B, B2C and Mixed Business Models
}

\begin{abstract}
This paper explores the implicit assumption in the growing body of literature that social media usage is fundamentally different in business-to-business $(B 2 B)$ companies than in the extant business-to-consumer (B2C) literature. Sashi's (2012) customer engagement cycle is utilized to compare $B 2 B, B 2 C$, Mixed $B 2 B / B 2 C$ and $B 2 B 2 C$ business model organizational practices in relation to social media usage, importance, and its perceived effectiveness as a communication channel. Utilizing 449 responses to an exploratory panel based survey instrument, we clearly identify differences in social media marketing usage and its perceived importance as a communications channel. In particular we identify distinct differences in the relationship between social media importance and the perceived effectiveness of social media marketing across business models. Our results indicate that B2B social media usage is distinct from B2C, Mixed and B2B2C business model approaches. Specifically B2B organizational members perceive social media to have a lower overall effectiveness as a channel and identify it as less important for relationship oriented usage than other business models.
\end{abstract}

Key Words: Social media; channel management; business-to-business marketing; B2B2C marketing; channel effectiveness

Funding Statement: This research did not receive any specific grant from funding agencies in the public, commercial, or not-for-profit sectors. 


\subsection{Introduction}

Towards the end of 2013, Volvo Trucks produced the 'Live Test' series of videos which drew heavily on conventional wisdom on Social Media Marketing (SMM) effectiveness (see Dobele, Lindgreen, Beverland, Vanhammer, \& Van Wijk, 2007) by including surprise humour, and a degree of jeopardy. Despite being targeted at a niche audience of fleet buyers, the videos have been viewed over 120m times on YouTube to date. While there can be little doubt that this campaign was a huge success in building brand awareness (Griner, 2014), it is unclear whether the Volvo campaign is an exception in its use of a business-to-consumer (B2C) SMM techniques in the business-to-business (B2B) domain, or one that can be generalised to reflect a broader level of B2B mimicry of B2C approaches.

The use of social media platforms as marketing channels has expanded in recent years, driven by the ability of firms to reach millions of customers with brand-related content and to engage them in conversations (Hanna, Rohm, \& Crittenden, 2011; Schivinski \& Dabrowski, 2016). The most influential papers on the subject are grounded in the B2C domain, and form the basis for the academic conception of how social media can be exploited to build brands and communicate with customers (Kaplan and Haenlein, 2010; Mangold \& Faulds, 2009; Kietzmann et al., 2011). Despite the emergence of studies that examine the use of SMM techniques by B2B organizations, our understanding of this important area is comparatively limited (Itani, Agnihotri \& Dingus, 2017; Siamagka, Christodoulides, Michaelidou, \& Valvi, 2015; Salo, 2017).

Extant literature largely assumes that the use of social media by B2B organizations is different, and therefore requires alternative theories (Salo, 2017). However, to date, only Moore, Hopkins, and Raymond (2013), Swani, Brown and Milne, (2014) and Swani, Milne, Brown, 
Assaf, and Donthu (2017) have empirically explored these differences; the first only in selling activities and the later two in terms of the relative content of social media posts (on Twitter and Facebook respectively). To date no paper explores differences in SMM usage across mixed business models, such as organizations selling to both business customers and consumers separately, or business-to-business-to-consumer (B2B2C) business models, where the direct customer is an organization, but marketing activities are targeted at the end consumer and intermediary simultaneously. This paper therefore takes a broader perspective than existing studies by comparing SMM usage and perceived effectiveness across a broader range of business models.

In terms of pure B2B / B2C comparisons, Moore et al. (2013), focuses particularly on selling activities through SMM, but existing B2B studies advocate the use of social media in all stages of the customer relationship (Guesalaga, 2016; Moncrief, Marshall, \& Rudd, 2015; Schultz, Schwepker, \& Good, 2012). Similarly, Swani and colleagues (2014; 2017), consider only content of social media posts, and not the role the content plays in the customer engagement cycle. A comparison of different business model approaches to SMM throughout the customer relationship is therefore currently lacking in the literature. Sashi (2012) develops a framework for exploring customer engagement cycles in social media in the B2C domain, but drawing from B2B theories of relationship marketing. Sashi elaborates on how the B2C relationship life cycles can be stimulated and managed using social media channels differently throughout the relationship cycle. By utilizing Sashi's framework to delineate between marketing activities that are oriented towards acquiring new customers; and those that are focused on developing relationships with existing customers, we provide a broader coverage than the three existing papers comparing B2B and B2C usage of SMM, but also respond to Sashi's own call for 
empirical validation of the framework in various contexts. The exploratory quantitative study in this paper therefore takes a broader perspective than existing studies by comparing SMM usage, importance, and perceived effectiveness across a range of business models and throughout the customer engagement cycle. We Explore a range of perspectives including usage intensity; channel selection; perceived importance to managers; and the stage in the relationship life-cycle, comparing pure B2B firms with their B2C, Mixed and B2B2C business model counter-parts. We then directly compare these business models, focusing on the extent to which SMM strategies are correlated with the perception of success in social media usage. We therefore contribute a broader exploration of the differences in social media usage across business models, highlighting the highest overall usage in $\mathrm{B} 2 \mathrm{~B} 2 \mathrm{C}$ organizations, and lowest perceived effectiveness in pure B2B organizations. We theoretically contribute by confirming difference in SMM usage at different stages of the customer life cycle, finding B2B firms to be more focused on SMM for acquisition oriented usage, rather than relationship orientated usage as explored by Moore et al. (2013). The paper is organized as follows: we provide an overview of SMM literature in the B2B domain, we outline our methodology, discuss our findings and conclude with limitations and recommendations for future research.

\subsection{Literature Review}

Social media in the context of B2C is widely researched, with its developed concepts and constructs, becoming an integral part of consumers' modern lives (Lamberton \& Stephen, 2016; Siamagka et al., 2015). This increase in popularity has been exploited in a number of ways in B2C, and often forms a large part of a company's marketing strategy (Ngai, Tao, \& Moon, 2015). Companies are able to communicate with consumers at a much lower cost than ever 
before through social media (Hainla, 2017; Neti, 2011), generating content online quickly and cheaply to develop brand presence (Ashley \& Tuten, 2015). However, the extent to which this theory is applicable to other business model domains such as B2B, Mixed B2C/B2B and B2B2C domains is currently empirically weak (Moore et al., 2013; Swani et al., 2017). Little to nothing is known about mixed business model organizations and although the B2B domain is growing, it is still in its theoretical infancy (Silo, 2017). The following sub-sections therefore explore the current literature regarding SMM in B2B domains, centred around four key areas: (1) types of business models; (2) marketing channel mix; (3) customer orientated social media usage; and (4) perceived SMM effectiveness. Each section provides an overview of the relevant literature, identifying the pertinent gaps and highlighting the research questions we seek to answer in this paper.

\subsubsection{Business Model Criticality}

Research in SMM has been dominated by a focus on interactions between businesses and consumers (Lacka \& Chong, 2016). A common theme being that social media channels provide an opportunity for both parties to engage in dialogue (Kietzmann et al., 2011). However, consistent with the notion that B2B marketing is different from B2C (Ellis, 2011), researchers have noted a general difference in social media adoption (Quinton \& Wilson, 2016), where the former has generally been slower in transitioning to this dialogical approach (Järvinen, Tollinen, Karjaluoto, \& Jayawardhena, 2012). Despite the common assumption of a difference in SMM usage between B2B and B2C organizations (Salo, 2017), the overall empirical evidence for this difference is limited, beyond B2B organizations being earlier in the adoption cycle. Moore et al., (2013) paper on selling activities was the first to directly explore differences in usage 
empirically, focusing on B2B organizations' more common usage of professional social networks such as LinkedIn, as opposed to B2C organizations' presence for mass-consumption social media such as Facebook. They also show that B2B organizations make more use of social media for dyadic relationship oriented purposes within the sales process than their B2C counterparts. Swani and colleagues $(2014 ; 2017)$ identify specific differences in the content of B2B and B2C SMM on both Twitter and Facebook respectively, especially in the extent to which B2B firms have more links and cues to product information, and focus on emotional messaging. Other than these studies, little has empirically explored differences in SMM usage across business models.

To dichotomize markets into B2B and B2C, is however overly simplistic (Leek \& Christodoulides 2011). We therefore consider two other common business models in this paper, neither of which have been studied for comparative SMM usage before: (1) 'mixed' refers to businesses that sell products to both other businesses and individual consumers (for example Amazon has many business customers and partners, as well as its B2C retail); (2) B2B2C refers to firms that, although directly earning revenue from organizational customers, manage customer experience (or the marketing of products and services) to the customers-customer, and down to the end consumer (Wiersema, 2013). B2B2C firms therefore market themselves simultaneously to both businesses and consumers. This is distinguished from 'mixed' businesses models by the need for individual transactions to ultimately require all three parties. Leek and Christodoulides (2011) cite the seminal 'Intel Inside' campaign, which equated the quality of a PC in consumers' minds with the presence of the firm's chip. Whilst Intel only 'sold' chips to electronics manufacturers, they developed their brand with consumers in order to create demand. More recent examples of B2B2C businesses are often based on e-commerce platforms such as Alibaba 
(Zhao \& Guo, 2012), and it is important to investigate B2B2C companies separately due to the differences in marketing approach between them and more dichotomous forms of business model (Järvinen et al., 2012; Zhao \& Guo, 2012). As identified above, the nature of any differences in the social media usage across the four types remains largely tacit, and this is a key driver for this paper, leading to our overarching research question:

\section{RQ1: To what extent is social media usage different in B2B organizations compared to B2C, Mixed and B2B2C business models?}

We consider this question from a number of different perspectives, which are outlined, and broken down in to sub-questions in the following sections.

\subsubsection{Channels Usage}

Effective channel usage can incorporate different mediums to serve different purposes. Although most SMM channels offer similar abilities to marketers (e.g. communicate content, target and engage consumers), different social media platform are perceived more favourably for certain forms of communications: Facebook is for providing a rich means for customer relationship management (Popp, Wilson, Horbel, \& Woratschek, 2016); Twitter is known for its ability to communicate brand messages and mining consumer responses in real-time (Culotta \& Cutler, 2016); Instagram is a means for sharing image-based content (Muñoz \& Towner, 2017); and YouTube for videos (Indvik, 2011). Although certain channels have strengths in different arenas, Pozza (2014) asserts that "better customer experience is driven by the presence of multiple channels" (p. 1274). 
Literature suggests B2C firms have been quick to adopt social media as a strategic tool, whereas B2B firms often find it difficult to identify and integrate the platforms into their digital marketing mix (Järvinen et al., 2012). Although social media enables organizations to increase the volume of potential relationship opportunities in $\mathrm{B} 2 \mathrm{~B}$, the channel management focus still remains narrowly focused on strategic network development, rather than on a many-to-many communications according to the literature (Arnaboldi \& Coget, 2016; Hennig-Thurau et al., 2010; Lee, Hwang, \& Lee, 2006; Muñoz \& Towner, 2017). Therefore, research in B2B often focuses on how social media is used in specific areas such as sales (Guesalaga, 2016; Itani et al. 2017), key account management (Lacoste, 2016), or employer-employee interactions (Kaur, 2015; Moser, Tumasjan, \& Welpe, 2016), rather than a broader consideration of the role it plays in the overall channel marketing mix.

Face-to-face selling is still considered to be the dominant form of communication for B2B organisations, although in reality only a fraction of the communication happens in person (Järvinen et al., 2012). Therefore literature shows B2B organizations viewing social media as a supportive tool to enhancing customer relationships, but the gap between potential and actual use of the channels remains large (Jussila et al., 2014). In B2B organizations, social media is used to enhance SEO (Search Engine Optimisation) driving traffic to home - and/or landing pages, thus resulting in customer engagement, customer service, and lead generation (Swani et al., 2014; Itani et al., 2017). Technology companies such as Dell, Intel and Oracle use Twitter for customer service, YouTube is used as a platform for webpage video integration, whereas LinkedIn is used to connect with clients and develop professional networking ties (Järvinen et al., 2012; Lacoste, 2016). Research shows that B2B practitioners use social media channels for targeting professionals, whereas their B2C counterparts use the channels to engage with the general public 
in one-on-one dialogue (Moore et al., 2013). Specifically, B2B sales professionals use social media marketing for prospecting, handling objections, and after sale follow-up (Moore et al., 2013). On the contrary, B2C salespeople value the connection with individual consumers (Moore et al., 2013).

The examples and the limited comparative research carried out show that B2B firms are able to exploit social media, but it is not clear how widespread usage is, or whether social media has been integrated, or how important it is perceived to be within marketing channel management (Brennan et al., 2011; Järvinen et al., 2012). Although sales-people are amongst the professionals who use relationship-oriented social media marketing to accomplish objectives (Moore et al., 2013), established digital tools such as e-newsletters and email marketing are suggested to still dominate the digital marketing mix within B2B organisations (Järvinen et al., 2012). To date, only Moore et al., (2013) has carried out comparative research investigating the utilization of relationship-oriented social media in the selling process. This research contributes to this gap in the literature by comparing the channel mix and SMM channel importance across different business models, leading to the following research questions:

RQ1a What differences exist in the relative usage of social media as part of the channel mix between B2B and other business models?

RQ1b What is the relative importance of different social media channels between B2B and other business models?

\subsubsection{Customer Orientated Usage of SMM}


B2B relationship marketing theories build our understanding of the different forms and structures of value creation between seller and buyer (Grönroos, 1994, 1996). They have been adopted into the consumer domain, encouraging a move from transactional to relational models, incorporating trust and commitment (Garbarino \& Johnson, 1999; Morgan \& Hunt, 1994). This has formed a focal theoretical lens for understanding social media usage in $\mathrm{B} 2 \mathrm{C}$ organizations (Hasani, Bojei, \& Dehghantanha, 2017; Lacoste, 2016; Sashi, 2012; Williams \& Chinn, 2010). Relationship marketing theory is specifically applied in social media research to explore how customer engagement; through social media, facilitates dialogue, which is a pre-requisite to developing desirable relationships between firms and consumers (Lacoste, 2016; Williams \& Chinn, 2010).

Sashi (2012) proposes a customer engagement framework that establishes social platforms as central to developing dialogue with customers throughout the relationship lifecycle. A key contribution of this work is the establishment of affective and calculative commitment between sellers and buyers, where they become co-creators of value. For consumer marketers, this was argued to be a recent possibility, enabled by the features of social media that allow customers to engage with each other and with the brand itself: a process described by Kietzmann et al. (2011) as democratizing communications. Further, Sashi elaborates the unique role played by social platforms at different stages of the relationship (for example, the role of communities as a source of pre-sales information, and as a way to engage in meaningful post-purchase dialogue with other users). Finally, Sashi proposes that the framework is cyclical, in the sense that engaged customers facilitate better connection with new prospects, both through advocacy and through dialogue. Sashi's (2012) framework is promising for application in a B2B context for two reasons: (1) it highlights various 'states' of the relationship which draw on B2B 
theorization in their lineage; and (2) provides useful guidance in the strategies necessary for firms to encourage transition from one stage to the next. The latter is a key area of focus for our study, and provides the theoretical underpinning for our identification of acquisition orientated and relationship orientated usage of SMM in organizations.

\subsubsection{Acquisition Orientation}

Acquisition orientation refers to the activities engaged in by firms to identify and interact with prospective customers and, specifically, where the aim is to engage them in their first transaction with the firm (Sashi, 2012). In relation to social media, this may include: using paid advertisements on social platforms (Stephen \& Galak, 2012); engaging influencers to promote or refer to the brand (Kozinets et al., 2010; Barry \& Gironda, 2017); or creating content that can virally spread, thus connecting new audiences with the brand (Popp et al., 2016; Pitt et al., 2017). The present study considers any activity that is designed to attract the attention and interest of new customers, to engage them in an initial interaction, and to guide them through the sales funnel towards the first sale as 'acquisition oriented'.

Specifically this relates to the first two stages of Sachi’s (2012) engagement model:

connection and interaction. The aim of the former is to match buyers: (1) who may be searching to meet known needs with sellers; (2) to facilitate serendipitous discovery; or (3) make introductions of new products and services to users who are browsing social media in a general way. Importantly, social media has the capacity to link potential customers with brands directly by following links to their own website (Leek et al., 2017; Swani et al., 2014), or by making direct connections within the platform itself, for example with a brand's own social media page (Pagani and Pardo, 2017; de Vries, Gensler \& Leeflang, 2012). 
Given that the focus of the social media literature in the acquisition phase is consumer oriented, it is currently unclear to what extent these techniques are echoed by B2B firms.

\subsubsection{Relationship Orientation}

Where we consider any activity designed to stimulate the initial transaction between buyer and seller 'acquisition orientated'; any interaction beyond this we categorised as 'relationship oriented' or part of the process of fulfilling the initial promises made (Grönroos 2009). In Sashi's (2012) conception, this involves: satisfaction (e.g. using social media to directly message customers with delivery or service details); retention (e.g. using cookies and remarketing techniques to remind customers of the brand and encourage them to return); connection (e.g. to create and promote content via social channels to customers to remind them of their relationship with the firm); advocacy (e.g. the active encouragement to recommend to others); engagement (i.e. the provision of channels for customers to interact with each other, and with members of the firm, in ways that are meaningful to both parties).

The aim of these activities is to drive a more committed and meaningful relationship between the brand and customers (Sashi, 2012). In the B2C context, these are referred to as 'creative consumers' who are producers of value-added content (Berthon, Pitt, Plangger, \& Shapiro, 2012), who are no longer passive recipients in the marketing exchange process (Hanna et al., 2011). Companies are also creating value on social media for customers through building online relationships, and simultaneously capturing value from the customer through raised brand awareness and new customer insights (Barwise \& Meehan, 2010; Kotler \& Armstrong, 2008). We therefore see relationship orientation with the emergence of many-to-many co-creation at the heart of social media in B2C (Hajli, 2013; Mount \& Martinez, 2014; Sashi, 2012). However it is 
unclear if this relationship orientation is used similarly in B2B organizations, where dyadic sales use has been most clearly articulated (Guesalaga, 2016; Moore et al., 2013; Siamagka et al., 2015) leading to our next research question:

\section{RQ1c Do B2B organizations place a different level of importance on social media usage for different stages of the relationship (acquisition vs. relationship orientation) compared to other business models?}

\subsubsection{Perceived Effectiveness of SMM}

Having so far concentrated our attention on the exploitation of digital channels for internal and external communications, our final research question focuses on the correlation between the customer relationship stage and the perceived effectiveness of SMM to the firm. Figure 1 outlines the conceptual model that underpins this enquiry, and this is elaborated in the following section.

[Insert Figure 1 about here]

While social media platforms are widely recognised by their relative ease of measurability (Järvinen et al., 2012), there is still uncertainty among marketers with respect to the value of SMM (Weinberg \& Pehlivan, 2011). This is reflected in contemporary practitioner discourse where it may be considered a 'fad' by many senior executives, which results in underinvestment (DeMers, 2017). Our dependent variable focuses on the perception of SMM effectiveness, and for this, we adopt Hoffman and Fodor's (2010) conceptualisation, where they 
stress that "returns from social media investments will not always be measured in dollars, but also in customer behaviours (consumer investments) tied to particular social media applications" (p. 42). Many B2B companies do not actively measure digital marketing performance, and measurement in general is not considered important (Järvinen et al., 2012), but it is important to establish how B2B organisations perceive SMM effectiveness.

\subsubsection{Acquisition vs Relationship Orientation}

Social media is accepted in the B2C domain as an appropriate channel across the full customer lifecycle: "awareness, information acquisition, opinions, attitudes, purchase behaviour, and post-purchase communication and evaluation" (Mangold \& Faulds, 2009, p.358), where consumers create, and can be active participants in the media process (Berthon et al., 2012; Dessart, Veloutsou, \& Morgan-Thomas, 2015). In this way they actively influence brand meanings and messages, and dictate product or service developments, which represents both an opportunity for companies to capitalize on online information, but also results in relinquishing control of key areas of competitive positioning (Dessart et al., 2015; Hanna et al., 2011). However, as outlined in Section 1.2.3, the nature of SMM activity may change dependent upon whether the firm wishes to attract the attention of potential customers, or establish on-going meaningful post-purchase dialogue (Sashi, 2012). Reflecting this, the conceptual model allows us to explore any differences between the broad categories under which these examples lie.

\subsubsection{Digital Channel Dominance}

Further, the conceptual model outlined in Figure 1 allows us to distinguish between traditional (offline) from digital (online) activities. By investigating the presence of a mediation effect between the independent variables: Acquisition Orientation (AO) and Relationship

Orientation (RO), and the dependent variable (Perceived Effectiveness of SMM), we are able to 
establish whether an overall greater digital focus in the marketing activities influence the extent to which SMM is valued. In other words, if the firm's marketing efforts are dominated by digital channels they may be more open to SMM.

\subsubsection{Moderating Effect of Business Model Category}

By comparing our four types of business models, we are able to establish differences that can inform whether SMM theory should be different for B2B firms compared to their colleagues in consumer-facing firms - a primary motivator for our paper. Prior theorisation suggests that B2B firms will focus more heavily on relationship activities (Salo, 2017), but in common with the general approach in our paper, we do not predict a direction or nature of relationships, but propose a research question that allows us to explore the phenomenon; thus:

\section{$\mathrm{RQ}_{2}$ Is the use of social media in different stages of the customer life-cycle correlated with perceived value and to what extent is this different between business models}

\subsection{Methodology}

To explore the extent to which B2B social media usage is different to other business models, this paper adopts an exploratory quantitative survey methodology, utilizing mixed methods of analysis. Explicit hypotheses are not set as the direction of hypotheses is unclear in the emerging B2B literature; therefore a more exploratory approach to analysis is adopted. A broad scale survey was adopted drawing on data from a mixed panel of marketing based employees in mixed sized organizations. The panel data distinguishes between four different 
types of respondent organization: (1) pure B2B; (2) pure B2C; (3) mixed B2B and B2C; and (4) B2B2C.

\subsubsection{Survey Development}

The survey was developed drawing on both the B2B literature (Brennan \& Croft, 2012; Michaelidou et al., 2011; Siamagka et al., 2015), and upon frameworks for SMM which were developed in the B2C domain (Culnan, McHugh, \& Zubillaga, 2010; Reilly \& Marx, 2013; Sashi, 2012). Specifically, we drew upon this literature to develop the survey in three sections focusing on: (1) the types of social media used in marketing efforts (derived from Kaplan \& Haenlein, 2010; Michaelidou et al., 2011; Solis, 2017): (2) the importance of these SMM channels to marketing managers (derived from Järvinen et al., 2012; Lacka \& Chong, 2016; Michaelidou et al., 2011); and (3) using SMM techniques to manage relationships with customers (derived from Brennan \& Croft, 2012; Quinton \& Wilson, 2016). Finally, recognizing the complexities of measuring social media effectiveness (Hoffman \& Fodor, 2010), and the exploratory nature of the study, we identified three complementary measures to create our Perceived Effectiveness of SMM scale (effective, successful and valuable). The individual questions asked are presented in the relevant data tables in the findings section.

\subsubsection{Sampling}

The data was collected through two panels (a university owned panel based on alumni data, and Qualtrics Panels). In order to maintain consistency of data, respondents were included only if they worked in the USA or UK (both early adopters of SMM, in the global top 10 for advertising spend in digital media, and with a common language thus avoiding potential issues in 
survey comprehension), and within marketing functions in their organizations. Two panels were used, as neither was large enough independently to provide our targeted 500 respondents from the specified regions, job titles, and mix of business types. The university database provided 137 responses, whereas the Qualtrics Panel data provided 377, giving an effective sample of 509. However, on further inspection, 60 respondents either did not work within the UK or USA, or failed to provide answers to all questions. Therefore, the working sample size was 449 (see Table 1 for participant company statistics). The equivalence of the US and UK samples was tested through a series of independent sample t-tests within the equivalence tool for SPSS created by Weber and Popova (2012), equivalence was largely maintained at the guide threshold delta of Cohens d = .2 (Stegner, Bostrom, \& Greenfield, 1996), however specific construct equivalence was sometimes uncertain at this guide level.

[Insert table 1 about here]

\subsubsection{Data Analysis}

To respond to the three parts of research question 1 , on the differences in social media usage between the four classifications of business, multi-group Tukey post-hoc ANOVAs were utilized. Lavene's Test for homogeneity of variance were almost universally non-significant, suggesting we can assume homogeneity of variance, thus Tukey was the appropriate post-hoc test. Research question 2, on the relationship between the perceived importance of channels, digital dominance, and perceived effectiveness of SMM, was tested using partial least squares structural equation modeling (PLS-SEM) which simultaneously measures the relationships between multiple constructs. PLS-SEM has been used extensively in the marketing literature to 
test theory, and has been particularly linked with exploratory studies such as this one. Further, it was suitable from a methodological perspective where a model includes formative measures (Hair, Ringle, \& Sarstedt, 2011). Finally, PLS has been linked with small samples and, while this was not an issue in the dataset as a whole, we needed to be careful of smaller groups for category analysis (Hair, Sarstedt, Ringle, \& Mena, 2012). The full details of the model and this approach are included in the second results section, as the first section of the results informed the model development.

\subsection{Findings}

The findings section is split into two sections, the first covering the three parts of research question 1 on the differences between B2B and the other three business models in terms of relative channel mix, the importance of social media channels and customer oriented SMM usage. The second section covers research question 2, exploring the relationship between the importance ascribed to social media usage, and the perceived effectiveness of SMM between business models.

\subsubsection{Identification of differences in B2B social media usage}

In response to research questions $1(\mathrm{a}, \mathrm{b} \& \mathrm{c})$ we explored differing approaches to channel usage, types of social media used, and the importance of social media for different marketing activities. Since the questions relate to differences in B2B social media usage compared to the three other business models (B2C, Mixed B2B and B2C, and B2B2C), the tables present significance scores between B2B and each of the other three business models (B2C, mixed and B2B2C); not significant difference between the three other business models. The data is 
presented this way to simplify data presentation and ensure clarity in response to the research questions. The mean for the B2B companies are in Bold where they have significant differences to all other business models, and are in italics where they are significantly different to only some of the other business models.

\subsubsection{Channel usage}

Research question 1a seeks to understand the difference in customer focused channel usage between B2B and the other business models. Table 2 presents the results of the Tukey post hoc ANOVA tests on the extent to which companies use different communication channels with customers. We identify significant differences in how B2B organizations communicate with customers compared to the other three business models. In direct comparison with pure B2C businesses, we see a significant divergence, with B2B organizations using one-to-many, impersonal marketing channels (print, traditional broadcast media, direct mail) with significantly less frequency than B2C organizations. Conversely the B2B organizations use one-to-one, personal marketing channels far more frequently (sales, company visits, telemarketing and tradeshows). In terms of many-to-many (i.e. social media) we also see a significant difference, with B2B organizations being significantly lower users than B2C organizations. One interesting phenomena to emerge from the analysis was that the B2B organizations were also significantly different to mixed business models and B2B2C in one-to-many and many-to-many channel usage (including social media), but not in one-to-one channels. Conversely B2C organizations were equivalent to mixed business models in many-to-many and one-to-many channels, but not one-to-one (although these significances are not reported here). This is consistent with the idea that mixed B2B / B2C organizations have to use channels consummate with pure B2B and pure 
B2C companies in the different parts of the business, and suggests respondents were able to answer for both sides of the business. This provides a high level of confidence in the data, because, at the level of channel usage, our results conform to traditional understandings of relative channel usage strategies (Ellis, 2011).

[Insert Table 2 here]

\subsubsection{Importance of Social Media Channels}

In terms of research question $1 \mathrm{~b}$ the importance of social media channels, a similar pattern emerges. In table 3 we see an almost universally lower level of importance ascribed to social media channels by pure B2B businesses, although not always significantly. In particular we see significant differences in the importance ascribed to traditional social networks, picture sharing sites, and review type media. The only social media platform for which B2B businesses are significantly bigger users is on business related social networks such as LinkedIn (as also found by Moore et al., 2013). Once again mixed model B2B / B2C businesses make similar usage levels to B2B companies in this media. We do however see mixed business models tend to consider all social media of higher importance than other business models. Again this could be due to the relative benefits of the different channels for each side of the business, or possibly that, in our sample, the mixed B2B / B2C businesses were slightly larger on average (see table 1), and the size of company may potentially affect the overall usage, and as such importance of social media - although further research would be needed on the impact of business size on social media adoption. The most interesting group however is the $\mathrm{B} 2 \mathrm{~B} 2 \mathrm{C}$ businesses, which are often described as frequent user of online media (Zhao \& Guo, 2012). They noticeably use 
ratings and reviews more than any other types of business, suggesting e-word of mouth (eWOM) may be important to these B2B2C businesses. This potentially makes sense considering the cobranded nature of a B2B2C organization. Both the B2B2C organization and their mediator to the consumer are likely to be co-branding at the point of purchase (think of Intel and a computer manufacturer). These businesses may therefore be more reliant on eWOM for communicating the benefits of their offering, than a B2C company that communicates directly with consumers.

[Insert table 3 here]

\subsubsection{Customer Orientated Usage of Social Media}

Research question 1c seeks to understand the relative importance of social media in managing customers between B2B and other business models. In the literature we identified a difference between Relationship Oriented usage and Acquisition Orientated usage based on Sashi's (2012) model. Table 4 therefore separates these two forms of usage, although this separation and wording was not used in the structure of the survey itself. Counter to Moore et al., (2013) we find that B2B organizations are using social media far less for Relationship Orientated usage purposes than the other business models. Again not all items are significant, but the direction of difference is consistent, and many differences are significant. This suggests social media is potentially less important, at the present time, for managing ongoing relationships in B2B organizations than for B2C, Mixed or B2B2C organizations. We also again see the B2B2C businesses ascribing high importance to social media in terms of providing customer service, and building customer relationships. 
In terms of Acquisition Orientated usage, which includes branding and awareness raising type activities, we see less difference in the use of social media. Other than the significantly lower usage by B2B, versus Mixed and B2B2C organizations on attracting new customers, we see only marginal significances between the different business types, and none between B2B and B2C businesses. The scores are also universally high ( $\sim 5$ out of 7$)$. This suggests all types of businesses ascribe similar importance to social media for acquisition related activities.

[Insert table 4 here]

\subsubsection{Perceived Effectiveness of SMM}

In response to research question 2 on the effectiveness of SMM, we see a continuing pattern from the usage of social media in B2B versus other business models. B2B organizations see social media as a less effective communication channel, and to have less potential as a channel for the business (see table 5). There does however appear to be a broad perception that it can be effective if managed properly, but at present there is a lack of belief in its usefulness compared to other communication channels.

\section{[Insert table 5 here]}

As previously outlined, relationship marketing has been a defining characteristic of B2B marketing strategies, recognizing that as the relationship between the buyer and seller develops and deepens, the nature of the communications also mature (Gummesson \& Grönroos, 2012). 
This becomes the focus of the second phase of our analysis. As outlined above, the theoretical basis of our model is Sashi's (2012) engagement cycle..

The relationship continuum was investigated in table 4 where we delineate between Acquisition Orientated usage (including awareness activities and brand development) and Relationship Orientated usage (which assumes the existence of a commercial relationship).

Noting the important differences between business models in the choice of channel (see table 2), we pay particular attention to the mediating role of digital channels. By focusing our mediator 'digital dominance' on only electronic channels (e.g. Web PR, search engine optimization), we are able to isolate a score for those who have high vs low prevalence of digital channel usage. This allows us to mediate for the higher digital dominance in B2C, B2B2C and mixed business models, and the potential effect this has on our dependent variable.

Sashi's model indicates that the goal of relationship marketing in a contemporary digital environment is an 'engaged consumer', but the identification of return on the investment (ROI) resulting from this is outside of the scope of his paper. Here, our dependent variable is the professional marketer's perception of effectiveness. In common with $R Q_{1}$, our independent variables are the Relationship Oriented vs Acquisition Oriented activities and we control for the channel to ensure we isolate the effect of social media as a digital strategy. This helps develop our understanding of the relationship between stages in the engagement lifecycle and perceived effectiveness of SMM. Further, through the use of multi-group analysis, we are able to observe differences between the four business models under investigation (See Table 5).

\subsubsection{Data Validation}


We used SmartPLS version 3.2 (Ringle, Wende \& Becker, 2016) and followed procedures outlined by Hair et al. (2014). Evaluation of outer and cross loadings indicates that items exceed the threshold of .708 in all cases. Further, each item loads more effectively to its own construct than to any other, indicating valid constructs. As shown in table 6, this is supported by reliability indicators that comfortably exceed the threshold of Composite Reliability and Cronbach's Alpha >.800 (Nunnally, 1978).

[Table 6 about here]

Data was assessed for discriminant validity by establishing that the Square Root of the Average Variance Extracted (AVE) was greater than the correlations between other constructs (See Table 7). We further validated discriminant validity using a measure recently proposed by Henseler et al. (2014) referred to as the Heterotrait-Monotrait (HTMT) ratio. In our data, the HTMT ratio met the required $<.900$ in all cases.

[Table 7 about here]

Finally, Variance Inflation Factor (VIF) indicates whether results may be inflated by multi-collinearity. Our data conformed to the required thresholds of VIF $>.2<5$ advocated by Hair et al. (2014). In summary, the validity tests indicated that our data met accepted thresholds for convergent validity, discriminant validity, reliability and multi-collinearity. While our primary aim was to test the specific relationships across the different business models, it is worth noting that the specified model meets the accepted threshold of acceptable fit as measured by 
standardized root mean square residual (SRMR) of .068 as noted by Henseler et al. (2014). Further the $\mathrm{R}_{2}$ of the dependent variable is acceptable (.382) given the relative scope of the model with a small number of independent variables.

\subsubsection{Testing the Paths}

Tests were conducted to assess the individual path co-efficients along with their corresponding $p$-value, reporting non-significant findings for completeness (see table 8). In line with Baron and Kenny (1986) we pre-tested the direct relationships between both orientations

and the dependent variable separately, noting significant paths $(p s<.05)$. By reviewing the direct effects vs. the total effects, we noted a greater path level co-efficient in all cases, indicating that the digital channel choice mediated the relationship between the orientations and the dependent variable. In both cases as the direct paths become non-significant, we can infer full mediation.

[Table 8 about here]

\subsection{Discussion}

It has been an assertion of the B2B literature to date that social media usage is fundamentally different to usage in B2C sectors (Brennan \& Croft, 2012; Guesalaga, 2016; Kaur, 2015; Lacoste, 2016; Moser et al., 2016; Quinton \& Wilson, 2016). In this paper we demonstrate that this is emphatically correct, particularly in respect to overall social media as part of the channel marketing strategy (RQ1a), the importance ascribed to SMM channels (RQ1b), the lower perceived importance of Relationship Orientated usage $\left(\mathrm{RQ}_{1 \mathrm{c}}\right)$ and the relationship between the 
importance of social media channels and their perceived effectives for marketing $\left(\mathrm{RQ}_{2}\right) . \mathrm{B} 2 \mathrm{~B}$ does therefore need its own theories of social media usage in addition to the $\mathrm{B} 2 \mathrm{C}$ theory.

One substantial contribution of this paper, however, is to include not only B2B and B2C organizations, but also mixed business models and B2B2C business models, which receive comparatively little analysis in the B2B marketing field. In doing so we find that; although the relative usage of social media as part of the overall marketing mix is lower in B2B than for B2C organizations, this does not hold for Mixed and B2B2C organizations who are among the highest users of social media. This difference relates to both (1) the types of channels used, and (2) the importance of that usage for different aspects of customer engagement and management. We see significant differences not only in the types of social media used; with only LinkedIn being more commonly used by B2B organizations and B2B2C, but also in the purpose it serves. Unlike the extant B2B literature which tends to focus on social media being used on the customer relationship interface (Guesalaga, 2016; Lacoste, 2016), we find less importance ascribed by pure B2B organizations to social media for relationship management than in other business models. Indeed, as shown in table 4, it is through thought leadership and corporate branding that B2B organizations are finding similar levels of importance in social media to their B2C and mixed model counterparts.

This raises interesting questions about the application of marketing theory in social media (Hasani et al., 2017; Lacoste, 2016; J. Williams \& Chinn, 2010). We find that B2B organizations perceive social media to have greater importance in the customer acquisition phases of Sashi's (2012) engagement cycle, with higher perceived importance given to Acquisition Orientated usage than Relationship Orientated usage. We also find that B2B organizations have lower relative levels of importance given to Relationship Orientated usage compared to other business 
models, but similar Acquisition Orientated usage. One possible explanation is that B2C literature has focused on relational marketing because businesses gain access to customers lived experience, insights and two-way dialogue via social media; data that traditionally costs a lot in terms of time and money in B2C (Kaplan \& Haenlein, 2011). B2B organizations however already have close relationships with existing customers, and therefore have access to insight into lived experience, and routes to ongoing dialogue (Ford, 1980; Grönroos, 1990). Therefore, B2B organizations gain something that was traditionally a poor return on investment to them - a means of mass-mediated communication, which spreads through social networks through eWOM. So, where we have seen B2B relationship marketing theory providing theoretical frameworks for B2C social media usage, there may be value in investigating B2B SMM through a mass-mediate consumer marketing lens. Particularly around issues of corporate branding, eWOM, viral marketing, and native advertising (as a form of thought leadership) (Chu \& Kim, 2011; Fulgoni \& Lipsman, 2014; Gylling \& Lindberg-Repo, 2006; Kaplan \& Haenlein, 2011). Taking this different approach to customer engagement further, research question 2 focuses on the perceived effectiveness of SMM in the Acquisition and Relational Orientated usage. We note some interesting and counter-intuitive findings in this area.

B2B organizations appear to view SMM as less important than their B2C, Mixed and B2B2C counterparts for relationship activities, but they rate them on par with the others when it comes to acquisition activities (see Table 4 in response to RQ1c). This is counter to extant theory, which suggests that B2B firms would focus more heavily on the importance of relationship activities (Moore et al., 2013). However, when taking into account the channel focus in the question, we speculate that B2B organizations see social media as important in developing reputation and initiating a relationship but beyond this, they rely on offline channels (e.g. face- 
to-face). This is in line with Lacoste's (2016) conclusions on social media in B2B key account management.

However, when we consider the relationship between self-reported importance of the channel (IV) with perceived effectiveness of SMM (DV) in our PLS-SEM analysis, we note an interesting result in relation to relationship marketing activities. B2B respondents, who consider social media to be an important digital strategy for this purpose, also perceive themselves to be overall more effective at it. This suggests that for some B2B organizations, social media represents an untapped resource that can be exploited more effectively. This supports the assertions of Moncreif et al. (2015) and Schultz et al. (2012) who say that social media has a place throughout the relationship life-cycle.

Overall we can therefore propose that B2B social media usage is distinct from B2C social media usage, particularly in terms of its role in managing customer relationships. Further, we note that this effect is exacerbated when we compare differences between those firms that are more digitally focused than the norm.

\subsection{Conclusion, Limitations and Future Research}

In summary, this paper confirms the (previously assumed) propensity of the extant B2B literature to treat social media usage as a different phenomenon to $\mathrm{B} 2 \mathrm{C}$ social media usage. Drawing on a survey of 449 UK and US business, we have been able to show that B2B companies use different social media channels, to serve different purposes, and with different perceived results. In particular, our final model suggests the use of social media, in terms of customer management at each of the new acquisition and ongoing relationship management stages, will be fundamentally different. A key contribution, of both theoretical and practical 
importance, is the somewhat surprising finding that B2B firms do not place importance or value on SMM as a strategy to develop relationships with their existing customers. This is bourn out by the Volvo Trucks example outlined at the start of this paper. Given the ability of social media platforms to facilitate one-to-one and one-to-many communications, this would seem an obvious opportunity to embed direct communications with members of client teams. We can speculate that the relationship between the importance with which SMM is viewed is an important factor in perception of effectives and the value it may bring across a range of tangible and intangible measures. Further, while the relationship is not specifically investigated here, there is a sense that low levels of usage may correlate with perceptions of importance and effectiveness. We speculate that the confidence of users may therefore be a key factor and that B2B firms may be more concerned about the risks of social media. This could also explain the reason why marketing professionals in those firms are on a par with their B2C counterparts in the earlystages of the relationship but less so later, where potentially large contract values are in jeopardy if negatively affected. Future qualitative research could uncover the underlying perceptions and motivations of the marketing decision-makers that could explain these relationships.

In addition, we suggest a greater need to investigate models of customer social media engagement in B2B companies, building relational development models including social media engagement, and identifying where social media interaction is of benefit to the overall marketing success of B2B organizations. There is also a wealth of research opportunity in mixed and B2B2C business models. So little is written about these models that the complementarity of working across the traditional pure B2B and B2C sectors may yield fresh new insights into customer management, and the overlap between B2B and B2C social media usage. 
However, this paper approached the topic from an exploratory and contextually abstracted level. It is therefore outside the scope of this paper to provide details of the particular nuances as to how social media is used differently in these spaces, both across business models, and across difference industrial sectors. The study is also limited to only two countries, and the survey was developed to gain insight into perceived importance, usage and effectiveness, none of which are direct measures of actual usage or outcome. There is also a potential for some overlap between the two databases we employ. Although we can be certain, due to the targeted nature of the mail out, that no company is represented more than once in either data base; for confidentiality reasons Qualitrics Panel does not provide a list of companies involved in the study. There is therefore a small chance of overlap between databases, but this should be minimal.

\subsection{References}

Alizadeh, A., \& Isa, R. M. (2015). The use of social media in destination marketing : An exploratory study. Journal of Customer Behaviour, 63(2), 175-193. Retrieved from http://web.b.ebscohost.com.ezproxy1.bath.ac.uk/ehost/pdfviewer/pdfviewer?sid=aed6b34bb655-4cf9-a4f3-0e328dc73510\%40sessionmgr101\&vid=1\&hid=129

Arnaboldi, M., \& Coget, J. F. (2016). Social media and business. We've been asking the wrong question. Organizational Dynamics, 45(1), 47-54.

http://doi.org/10.1016/j.orgdyn.2015.12.006

Ashley, C., \& Tuten, T. (2015). Creative Strategies in Social Media Marketing: An Exploratory Study of Branded Social Content and Consumer Engagement. Psychology \& Marketing, 
33(1), 15-27. http://doi.org/10.1002/mar

Baron, R., \& Kenny, D. (1986). The moderator-mediator variable distinction in social psychological research. Journal of Personality and Social Psychology, 51(6), 1173-1182. http://doi.org/10.1037/0022-3514.51.6.1173

Barry, J. M., \& Gironda, J. T. (2017). Operationalizing thought leadership for online B2B marketing. Industrial Marketing Management, (October), 1-22. http://doi.org/10.1016/j.indmarman.2017.11.005

Barwise, P., \& Meehan, S. (2010). The one thing you must get right when building a brand. Harvard Business Review, 88(12), 80-84.

Berthon, P. R., Pitt, L. F., Plangger, K., \& Shapiro, D. (2012). Marketing meets Web 2.0, social media, and creative consumers: Implications for international marketing strategy. Business Horizons, 55(3), 261-271. http://doi.org/10.1016/j.bushor.2012.01.007

Brennan, R., Canning, L., \& McDowell, R. (2011). Business-to-business marketing. SAGE.

Chu, S. C., \& Kim, Y. (2011). Determinants of consumer engagement in electronic Word-OfMouth (eWOM) in social networking sites. International Journal of Advertising, 30(1), 4775. http://doi.org/10.2501/IJA-30-1-047-075

Culnan, M. J., McHugh, P. J., \& Zubillaga, J. I. (2010). How Large U.S. Companies Can Use Twitter and Other Social Media to Gain Business Value. MIS Quarterly Executive, 9(4), $243-259$.

Culotta, A., \& Cutler, J. (2016). Mining Brand Perceptions from Twitter Social Networks. Marketing Science, 35(3), 343-362. http://doi.org/10.1287/mksc.2015.0968

De Vries, L., Gensler, S., \& Leeflang, P. S. H. (2012). Popularity of Brand Posts on Brand Fan Pages: An Investigation of the Effects of Social Media Marketing. Journal of Interactive 
Marketing, 26, 83-91. http://doi.org/10.1016/j.intmar.2012.01.003

Dessart, L., Veloutsou, C., \& Morgan-Thomas, A. (2015). Consumer engagement in online brand communities: a social media perspective. Journal of Product \& Brand Management, 24(1), 28-42. http://doi.org/10.1108/JPBM-06-2014-0635

Dobele, A., Lindgreen, A., Beverland, M., Vanhamme, J., \& van Wijk, R. (2007). Why pass on viral messages? Because they connect emotionally. Business Horizons, 50(4), 291-304. http://doi.org/10.1016/j.bushor.2007.01.004

Ellis, N. (2011). Business to Business Marketing: Relationships, networks and strategies.

Ford, D. (1980). The Development of Buyer-Seller Relationships in Industrial Markets. European Journal of Marketing. 14(5/6), 339-353

Fulgoni, G., \& Lipsman, A. (2014). Numbers, please: Digital game changers: How social media will help usher in the era of mobile and multi-platform campaign-effectiveness measurement. Journal of Advertising Research, 54(1), 11-16. http://doi.org/10.2501/JAR54-1-011-016

Garbarino, E., \& Johnson, M. S. (1999). The Different Roles of Satisfaction, Trust, and Commitment in Customer Relationships. American Marketing Association, 63(2), 70-87. http://doi.org/10.2307/1251946

Griner, D. (2014). Undivided Attention: How "Epic Split” Became the Buzziest Ad at Cannes Adweek. Retrieved December 19, 2017, from http://www.adweek.com/brandmarketing/undivided-attention-how-epic-split-became-buzziest-ad-cannes-158248/

Grönroos, C. (1990). Service management and marketing : managing the moments of truth in service competition. Lexington Books.

Grönroos, C. (1994). From Marketing Mix to Relationship Marketing : Management Decision, 


$$
\text { 32(2), 4-20. }
$$

Grönroos, C. (1996). Relationship marketing: strategic and tactical implications. Management Decision, 34, 5-14. http://doi.org/10.1108/00251749610113613

Grönroos, C. (2009). Marketing as promise management: regaining customer management for marketing. Journal of Business \& Industrial Marketing, 24(5/6), 351-359. http://doi.org/10.1108/08858620910966237

Guesalaga, R. (2016). The use of social media in sales: Individual and organizational antecedents, and the role of customer engagement in social media. Industrial Marketing Management, 54, 71-79. http://doi.org/10.1016/j.indmarman.2015.12.002

Gummesson, E., \& Grönroos, C. (2012). The emergence of the new service marketing: Nordic School perspectives. Journal of Service Management, 23(4), 479-497.

Gylling, C., \& Lindberg-Repo, K. (2006). Investigating the links between a corporate brand and a customer brand. Journal of Brand Management, 13(4-5), 257-267. http://doi.org/10.1057/palgrave.bm.2540269

Hainla, L. (2017). 21 Social Media Marketing Statistics You Need to Know in 2017 DreamGrow. Retrieved January 30, 2017, from https://www.dreamgrow.com/21-socialmedia-marketing-statistics/

Hair, J. F., Ringle, C. M., \& Sarstedt, M. (2011). PLS-SEM: Indeed a Silver Bullet. The Journal of Marketing Theory and Practice, 19(2), 139-152. http://doi.org/10.2753/MTP10696679190202

Hair, J. F., Sarstedt, M., Ringle, C. M., \& Mena, J. A. (2012). An assessment of the use of partial least squares structural equation modeling in marketing research. Journal of the Academy of Marketing Science, 40(3), 414-433. http://doi.org/10.1007/s11747-011-0261-6 
Hajli, M. N. (2013). A study of the impact of social media on consumers. International Journal of Market Research, 56(3), 387-404.

Hanna, R., Rohm, A., \& Crittenden, V. L. (2011). We're all connected: The power of the social media ecosystem. Business Horizons, 54(3), 265-273. http://doi.org/10.1016/j.bushor.2011.01.007

Hasani, T., Bojei, J., \& Dehghantanha, A. (2017). Investigating the antecedents to the adoption of SCRM technologies by start-up companies. Telematics and Informatics, 34(5), 655-675. http://doi.org/10.1016/j.tele.2016.12.004

Hennig-Thurau, T., Malthouse, E. C., Friege, C., Gensler, S., Lobschat, L., Rangaswamy, A., \& Skiera, B. (2010). The Impact of New Media on Customer Relationships. Journal of Service Research, 13((3)), 311-330. http://doi.org/10.1177/1094670510375460

Henseler, J., Ringle, C. M., \& Sarstedt, M. (2014). A new criterion for assessing discriminant validity in variance-based structural equation modeling. Journal of the Academy of Marketing Science, 43(1), 115-135. http://doi.org/10.1007/s11747-014-0403-8

Hoffman, D. ., \& Fodor, M. (2010). Can You Measure the ROI of Your Social Media Marketing? MIT Sloan Management Review, 52(1), 41-49.

Indvik, L. (2011). Why Fashion's Top Brands Are Flocking to Tumblr. Retrieved January 30, 2017, from http://mashable.com/2011/02/06/fashion-tumblr-kate-spade/\#ankMZrA0kOq3

Itani, O. S., Agnihotri, R., \& Dingus, R. (2017). Social media use in B2b sales and its impact on competitive intelligence collection and adaptive selling: Examining the role of learning orientation as an enabler. Industrial Marketing Management, 66(June), 64-79. http://doi.org/10.1016/j.indmarman.2017.06.012

Järvinen, J., Tollinen, A., Karjaluoto, H., \& Jayawardhena, C. (2012). Digital and social media 
marketing usage in b2b industrial section. Marketing Management Journal, 22(2), 102-117.

Hair, J. F., Hult, G. T. M., Ringle, C. M., \& Sarstedt, M. (2014). A primer on partial least squares structural equation modeling (PLS-SEM). SAGE.

Jussila, J. J., Kärkkäinen, H., \& Aramo-Immonen, H. (2014). Social media utilization in business-to-business relationships of technology industry firms. Computers in Human Behavior, 30, 606-613. http://doi.org/10.1016/j.chb.2013.07.047

Kaplan, A. M., \& Haenlein, M. (2010). Users of the world, unite! The challenges and opportunities of Social Media. Business Horizons, 53, 59-68. http://doi.org/10.1016/j.bushor.2009.09.003

Kaplan, A. M., \& Haenlein, M. (2011). Two hearts in three-quarter time: How to waltz the social media/viral marketing dance. Business Horizons, 54(3), 253-263. http://doi.org/10.1016/j.bushor.2011.01.006

Kaur, P. (2015). Using Social Media for Employer Branding and Talent Management: An Experiential Study. Journal of Brand Management, 7(2), 7-20.

Kietzmann, J. H., Hermkens, K., McCarthy, I. P., \& Silvestre, B. S. (2011). Social media? Get serious! Understanding the functional building blocks of social media. Business Horizons, 54(3), 241-251. http://doi.org/10.1016/j.bushor.2011.01.005

Kotler, P., \& Armstrong, G. (2008). Principles of Marketing. Financial Times/ Prentice Hall; 5 edition.

Kozinets, R. V, de Valck, K., Wojnicki, A. C., \& Wilner, S. J. . (2010). Networked Narratives: Understanding Word-of-Mouth Marketing in Online Communities. Journal of Marketing, 74(2), 71-89. http://doi.org/10.1509/jmkg.74.2.71

Lacka, E., \& Chong, A. (2016). Usability perspective on social media sites' adoption in the B2B 
context. Industrial Marketing Management, 54, 80-91. http://doi.org/10.1016/j.indmarman.2016.01.001

Lacoste, S. (2016). Perspectives on social media ant its use by key account managers. Industrial Marketing Management, 54, 33-43. http://doi.org/10.1016/j.indmarman.2015.12.010

Lamberton, C., \& Stephen, A. T. (2016). A Thematic Exploration of Digital, Social Media, and Mobile Marketing: Research Evolution from 2000 to 2015 and an Agenda for Future Inquiry. Journal of Marketing, 80(6), 146-172. http://doi.org/10.1509/jm.15.0415

Lee, S., Hwang, T., \& Lee, H.-H. (2006). Corporate blogging strategies of the Fortune 500 companies. Management Decision, Vol. 44(No.3), 316-334. http://doi.org/http://dx.doi.org/10.1108/MRR-09-2015-0216

Leek, S., \& Christodoulides, G. (2011). A literature review and future agenda for B2B branding: Challenges of branding in a B2B context. Industrial Marketing Management, 40, 830-837. http://doi.org/10.1016/j.indmarman.2011.06.006

Leek, S., Houghton, D., \& Canning, L. (2017). Twitter and behavioral engagement in the healthcare sector: An examination of product and service companies. Industrial Marketing Management, (October). http://doi.org/https://doi.org/10.1016/j.indmarman.2017.10.009

Mangold, W. G., \& Faulds, D. J. (2009). Social media: The new hybrid element of the promotion mix. Business Horizons, 52, 357-365. http://doi.org/10.1016/j.bushor.2009.03.002

Michaelidou, N., Siamagka, N. T., \& Christodoulides, G. (2011). Usage, barriers and measurement of social media marketing: An exploratory investigation of small and medium B2B brands. Industrial Marketing Management, 40(7), 1153-1159. http://doi.org/10.1016/j.indmarman.2011.09.009

Moncrief, W. C., Marshall, G. W., \& Rudd, J. M. (2015). Social media and related technology: 
Drivers of change in managing the contemporary sales force. Business Horizons, 58(1), 4555. http://doi.org/10.1016/j.bushor.2014.09.009

Moore, J. N., Hopkins, C. D., \& Raymond, M. A. (2013). Utilization of Relationship-Oriented Social Media in the Selling Process: A Comparison of Consumer (B2C) and Industrial (B2B) Salespeople. Journal of Internet Commerce, 12(1), 48-75. http://doi.org/10.1080/15332861.2013.763694

Morgan, R. M., \& Hunt, S. D. (1994). The Commiment-Trust Theory of Relationship Marketing. Journal of Marketing, 58(3), 20-38.

Moser, K., Tumasjan, A., \& Welpe, I. (2016). Content is king: what makes an engaging recruitment brand on social media channels? In Academy of Marketing, 43-49.

Mount, M., \& Martinez, M. G. (2014). Social Media. California Management Review, 56(4), 124-144. http://doi.org/10.1525/cmr.2014.56.4.124

Muñoz, C. L., \& Towner, T. L. (2017). The Image is the Message: Instagram Marketing and the 2016 Presidential Primary Season. Journal of Political Marketing, 7857(June), 15377857.2017.1334254. http://doi.org/10.1080/15377857.2017.1334254

Neti, S. (2011). Social media and its role in marketing. International Journal of Enterprise Computing and Business Systems, 1, 1-15. http://doi.org/10.4172/2151-6219.1000203

Ngai, E. W. T., Tao, S. S. C., \& Moon, K. K. L. (2015). Social media research: Theories, constructs, and conceptual frameworks. International Journal of Information Management, 35(1), 33-44. http://doi.org/10.1016/j.ijinfomgt.2014.09.004

Nunnally, J. C. (1978). Psychometric theory. McGraw-Hill.

Pagani, M., \& Pardo, C. (2017). The impact of digital technology on relationships in a business network. Industrial Marketing Management, 67(September 2016), 185-192. 
http://doi.org/10.1016/j.indmarman.2017.08.009

Pitt, C., Plangger, K., Botha, E., Kietzmann, J., \& Pitt, L. (2017). How employees engage with B2B brands on social media: Word choice and verbal tone. Industrial Marketing Management, (January), 0-1. http://doi.org/10.1016/j.indmarman.2017.09.012

Popp, B., Wilson, B., Horbel, C., \& Woratschek, H. (2016). Relationship building through Facebook brand pages: the multifaceted roles of identification, satisfaction, and perceived relationship investment. Journal of Strategic Marketing, 24(3-4), 278-294. http://doi.org/10.1080/0965254X.2015.1095226

Pozza, I. (2014). Multichannel management gets “social.” European Journal of Marketing, 48(7/8), 1274-1295. http://doi.org/10.1108/EJM-10-2012-0598

Quinton, S., \& Wilson, D. (2016). Tensions and ties in social media networks: Towards a model of understanding business relationship development and business performance enhancement through the use of LinkedIn. Industrial Marketing Management, 54, 15-24. http://doi.org/10.1016/j.indmarman.2015.12.001

Reilly, K. O., \& Marx, S. (2013). Why people use social media: a uses and gratifications approach. Qualitative Market Research: An International Journal, 16(4), 362-369. Retrieved from https://doi.org/10.1108/ QMR-06-2013-0041

Ringle, C. M., Wende, S., \& Becker, J.-M.-. (2015). SmartPLS 3. Retrieved December 19, 2017, from https://www.smartpls.com/

Salo, J. (2017). Social media research in the industrial marketing field: Review of literature and future research directions. Industrial Marketing Management, 66(August), 115-129. http://doi.org/10.1016/j.indmarman.2017.07.013

Sashi, C. M. (2012). Customer engagement, buyer-seller relationships, and social media. 
Management Decision, 50(2), 253-272.

Schivinski, B., \& Dabrowski, D. (2016). The effect of social media communication on consumer perceptions of brands. Journal of Marketing Communications, 22(2), 189-214. http://doi.org/10.1080/13527266.2013.871323

Schultz, R. J., Schwepker, C. H., \& Good, D. J. (2012). An Exploratory Study of Social Media In Business-To-Business Selling: Salesperson Characteristics, Activities And Performance. Marketing Management Journal, 22(2), 76-89. Retrieved from http://www.mmaglobal.org/publications/marketingmanagementjournal.html

Siamagka, N.-T., Christodoulides, G., Michaelidou, N., \& Valvi, A. (2015). Determinants of social media adoption by B2B organizations. Industrial Marketing Management, 51, 89-99. http://doi.org/10.1016/j.indmarman.2015.05.005

Siamagka, N. T., Christodoulides, G., Michaelidou, N., \& Valvi, A. (2015). Determinants of social media adoption by B2B organizations. Industrial Marketing Management, 51, 89-99. http://doi.org/10.1016/j.indmarman.2015.05.005

Solis, B. (2017). The Conversation Prism. Retrieved June 14, 2017, retrived from https://conversationprism.com/

Stegner, B. L., Bostrom, A. G., \& Greenfield, T. K. (1996). Equivalence testing for use in psychosocial and services research: An introduction with examples. Evaluation and Program Planning, 19(3), 193-198. http://doi.org/10.1016/0149-7189(96)00011-0

Stephen, A. T., \& Galak, J. (2012). The Effects of Traditional and Social Earned Media on Sales: A Study of a Microlending Marketplace. Journal of Marketing Research, 49(October), 624639. http://doi.org/10.1509/jmr.09.0401

Swani, K., Brown, B. P., \& Milne, G. R. (2014). Should tweets differ for B2B and B2C? An 
analysis of Fortune 500 companies' Twitter communications. Industrial Marketing Management, 43(5), 873-881. http://doi.org/10.1016/j.indmarman.2014.04.012

Swani, K., Milne, G. R., Brown, B. P., Assaf, A. G., \& Donthu, N. (2017). What messages to post? Evaluating the popularity of social media communications in business versus consumer markets. Industrial Marketing Management, 62, 77-87. http://doi.org/10.1016/j.indmarman.2016.07.006

Weber, R., \& Popova, L. (2012). Testing Equivalence in Communication Research: Theory and Application. Communication Methods and Measures, 6(3), 190-213. http://doi.org/10.1080/19312458.2012.703834

Weinberg, B. D., \& Pehlivan, E. (2011). Social spending: Managing the social media mix. Business Horizons, 54(3), 275-282. http://doi.org/10.1016/j.bushor.2011.01.008

Wiersema, F. (2013). The B2B Agenda: The current state of B2B marketing and a look ahead. Industrial Marketing Management, 42, 470-488. http://doi.org/10.1016/j.indmarman.2013.02.015

Williams, J., \& Chinn, S. J. (2010). Meeting Relationship-Marketing Goals through Social Media: A Conceptual Model for Sport Marketers. International Journal of Sport Communication, 3(4), 422-437. http://doi.org/10.1123/ijsc.3.4.422

Zhao, L., \& Guo, S. (2012). The Value Creation of B2B2C E-Business Mode based on SaaS. Journal of Electronic Commerce in Organizations, 10(3), 1-12. http://doi.org/10.4018/jeco.2012070101 
Figure 1: Conceptual Model

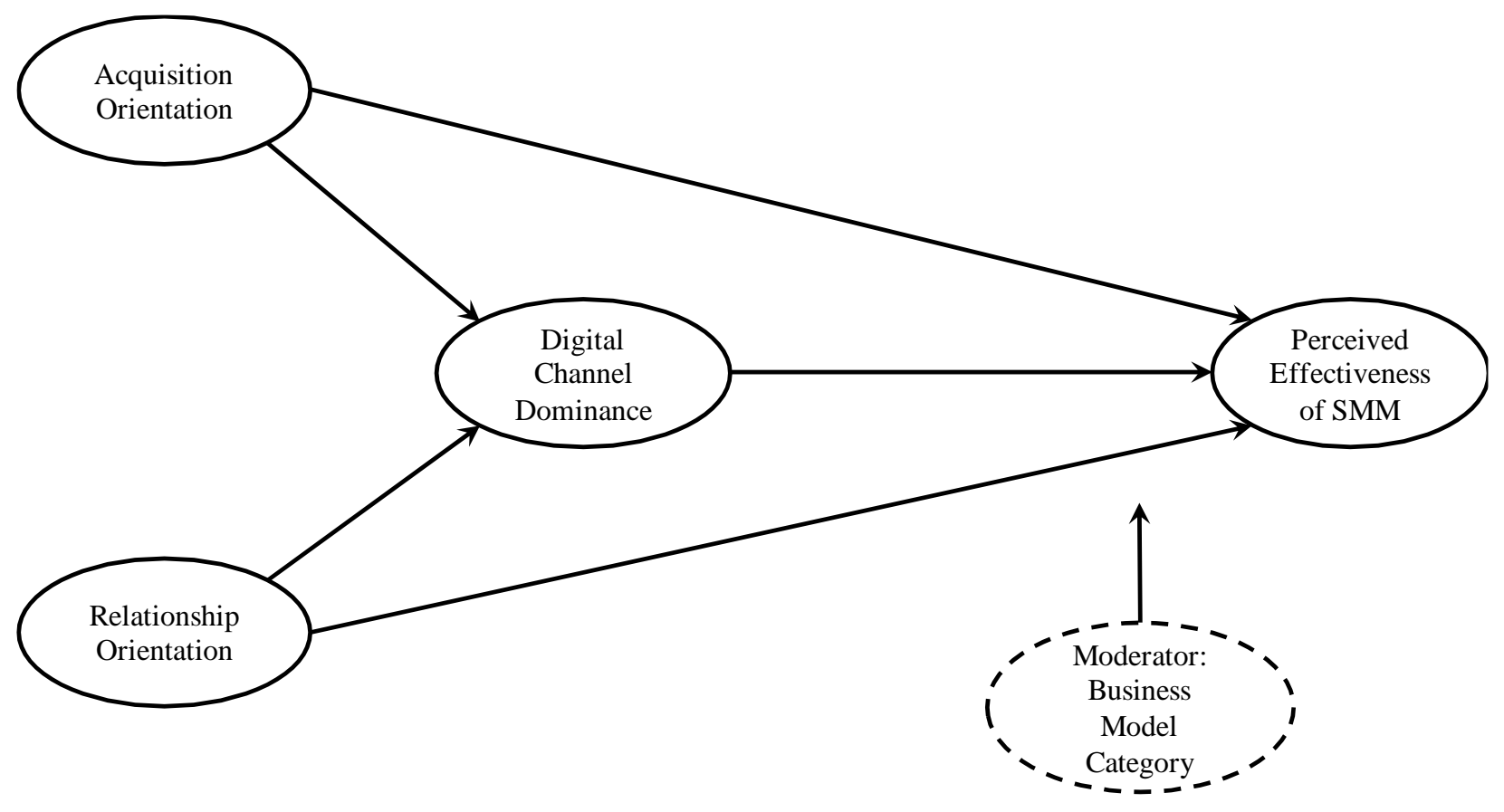


Table 1:

Participant company statistics

\begin{tabular}{|l|c|c|c|c|c|}
\hline & Totals & B2B & B2C & Mixed & B2B2C \\
\hline Country & 449 & 109 & 146 & 151 & 43 \\
\hline UK & 180 & 60 & 53 & 58 & 7 \\
\hline USA & 269 & 49 & 93 & 93 & 36 \\
\hline
\end{tabular}

\begin{tabular}{|l|c|c|c|c|c|}
\hline Business Size (no. Employees) & 449 & B2B & B2C & Mixed & B2B2C \\
\hline$<50$ & 103 & $28 \%$ & $28 \%$ & $14 \%$ & $23 \%$ \\
\hline $50-99$ & 47 & $11 \%$ & $10 \%$ & $12 \%$ & $7 \%$ \\
\hline $100-499$ & 87 & $17 \%$ & $19 \%$ & $22 \%$ & $16 \%$ \\
\hline $500-999$ & 38 & $11 \%$ & $10 \%$ & $7 \%$ & $2 \%$ \\
\hline $1000-1999$ & 32 & $5 \%$ & $6 \%$ & $8 \%$ & $14 \%$ \\
\hline $2000-4999$ & 49 & $9 \%$ & $8 \%$ & $14 \%$ & $14 \%$ \\
\hline$>5000$ & 93 & $18 \%$ & $18 \%$ & $24 \%$ & $23 \%$ \\
\hline
\end{tabular}

\begin{tabular}{|l|c|c|c|c|c|}
\hline Industry classification & 449 & B2B & B2C & Mixed & B2B2C \\
\hline $\begin{array}{l}\text { Mechanical Engineering, } \\
\text { Manufacturing and process industries }\end{array}$ & 48 & $30 \%$ & $26 \%$ & $30 \%$ & $13 \%$ \\
\hline Online Retailer & 23 & $4 \%$ & $52 \%$ & $39 \%$ & $4 \%$ \\
\hline Internet service provider & 11 & $45 \%$ & $18 \%$ & $27 \%$ & $9 \%$ \\
\hline Communication carrier & 9 & $22 \%$ & $0 \%$ & $78 \%$ & $0 \%$ \\
\hline Banking and Finance & 12 & $17 \%$ & $25 \%$ & $50 \%$ & $8 \%$ \\
\hline Professional Service \& consulting & 42 & $25 \%$ & $27 \%$ & $34 \%$ & $14 \%$ \\
\hline Government & 14 & $21 \%$ & $50 \%$ & $21 \%$ & $7 \%$ \\
\hline Healthcare & 21 & $14 \%$ & $33 \%$ & $38 \%$ & $14 \%$ \\
\hline Transport and utilities & 11 & $27 \%$ & $27 \%$ & $36 \%$ & $9 \%$ \\
\hline $\begin{array}{l}\text { Construction, Architecture, Civil } \\
\text { Engineering }\end{array}$ & 19 & $16 \%$ & $16 \%$ & $58 \%$ & $11 \%$ \\
\hline Data Processing & 4 & $50 \%$ & $0 \%$ & $50 \%$ & $0 \%$ \\
\hline Wholesale, Retail or distribution & 64 & $11 \%$ & $39 \%$ & $34 \%$ & $16 \%$ \\
\hline Education & 15 & $20 \%$ & $47 \%$ & $27 \%$ & $7 \%$ \\
\hline Marketing, advertising & 42 & $40 \%$ & $26 \%$ & $24 \%$ & $10 \%$ \\
\hline IT & 48 & $50 \%$ & $13 \%$ & $35 \%$ & $2 \%$ \\
\hline Other & 66 & & & & \\
\hline
\end{tabular}




\section{Table 2: Channel Usage}

How often does your company use the below marketing channels for communicating with customers? (Reversed)

(1=never, $7=$ =always $)$

\begin{tabular}{|c|c|c|c|c|c|c|c|c|c|c|c|c|}
\hline & \multicolumn{2}{|c|}{ Direct Mail } & \multicolumn{2}{|l|}{ Print } & \multicolumn{2}{|c|}{ Web PR } & \multicolumn{2}{|c|}{ Telemktg } & \multicolumn{2}{|c|}{$\begin{array}{l}\text { Traditional } \\
\text { Broadcast }\end{array}$} & \multicolumn{2}{|c|}{$\begin{array}{l}\text { Online } \\
\text { Broadcast }\end{array}$} \\
\hline $\mathrm{B} 2 \mathrm{~B}$ & 3.1 & Sig. & 2.93 & Sig. & 4.04 & Sig. & 2.92 & Sig. & 1.53 & Sig. & 2.35 & Sig. \\
\hline B2C & $3.72 *$ & .047 & $3.49 *$ & .048 & 3.99 & .999 & $2.23 *$ & 年. & $2.58 * *$ & .000 & 2.81 & .264 \\
\hline Mixed & $4.29 * *$ & .000 & $4.05 * *$ & .000 & 4.39 & .298 & 3.21 & .637 & $3.12 * *$ & .000 & $3.7 * *$ & .000 \\
\hline B2B2C & 3.56 & .351 & $4.1 * *$ & .002 & 4.09 & .993 & 2.53 & .767 & $2.88 * *$ & .001 & $4.02 * *$ & .000 \\
\hline
\end{tabular}

\begin{tabular}{|c|c|c|c|c|c|c|c|c|c|c|}
\hline \multirow[b]{2}{*}{$\mathrm{B} 2 \mathrm{~B}$} & \multicolumn{2}{|c|}{ Trade shows } & \multicolumn{2}{|c|}{ Social media } & \multicolumn{2}{|l|}{$\begin{array}{l}\text { Face-to } \\
\text {-Face }\end{array}$} & \multicolumn{2}{|c|}{$\begin{array}{l}\text { Company } \\
\text { Visits }\end{array}$} & \multicolumn{2}{|c|}{$\begin{array}{l}\text { Search } \\
\text { Engine } \\
\text { optimization }\end{array}$} \\
\hline & 3.21 & Sig. & 3.89 & Sig. & 4.62 & Sig. & 4.46 & Sig & 3.61 & Sig. \\
\hline $\mathrm{B} 2 \mathrm{C}$ & $2.15^{* *}$ & .000 & $4.45^{*}$ & .032 & $4.06^{*}$ & .028 & $3.38 * *$ & .000 & 3.44 & .941 \\
\hline Mixed & 3.25 & .994 & $4.67 * *$ & .001 & 4.48 & .912 & 4.18 & .691 & $4.25^{* *}$ & .031 \\
\hline $\mathrm{B} 2 \mathrm{~B} 2 \mathrm{C}$ & 2.49 & .192 & 4.12 & .840 & 4.4 & .868 & 4.09 & .726 & 3.72 & .977 \\
\hline
\end{tabular}




\section{Table 3: Importance of Social Media Channels}

How important are each of the following forms of social media to your marketing efforts?

$(1=$ not important, 7 extremely important $)$

\begin{tabular}{|l|l|l|l|l|l|l|l|l|l|l|}
\hline & $\begin{array}{l}\text { Social } \\
\text { Networks } \\
\text { (E.g. } \\
\text { Facebook, } \\
\text { Google+) }\end{array}$ & $\begin{array}{l}\text { Blog (E.g. } \\
\text { TypePad, } \\
\text { Squarespace, } \\
\text { eBlogger) }\end{array}$ & $\begin{array}{l}\text { Crowd } \\
\text { wisdom } \\
\text { (e.g.BuzzFeed, } \\
\text { reddit, } \\
\text { newsvine) }\end{array}$ & $\begin{array}{l}\text { Q\&A (E.g. } \\
\text { Yahoo } \\
\text { answers, } \\
\text { Quora, } \\
\text { AllExperts) }\end{array}$ & $\begin{array}{l}\text { Social } \\
\text { streams } \\
\text { (E.g. } \\
\text { Twitter, } \\
\text { app.net, aol) }\end{array}$ \\
\hline B2B & $\mathbf{5 . 4 2}$ & Sig. & 4.29 & Sig. & 3.45 & Sig. & 3.34 & Sig. & 5.35 & Sig. \\
\hline B2C & $6.47^{* *}$ & .000 & 4 & .782 & 3.31 & .970 & 3.77 & .533 & 5.46 & .980 \\
\hline Mixed & $6.4^{* *}$ & .000 & 4.91 & .195 & $4.32^{*}$ & .027 & $4.57 * *$ & .001 & 5.82 & .301 \\
\hline B2B2C & $6.51^{* *}$ & .009 & 4.28 & 1.000 & 3.86 & .785 & $4.6^{*}$ & .026 & 5.79 & .656 \\
\hline
\end{tabular}

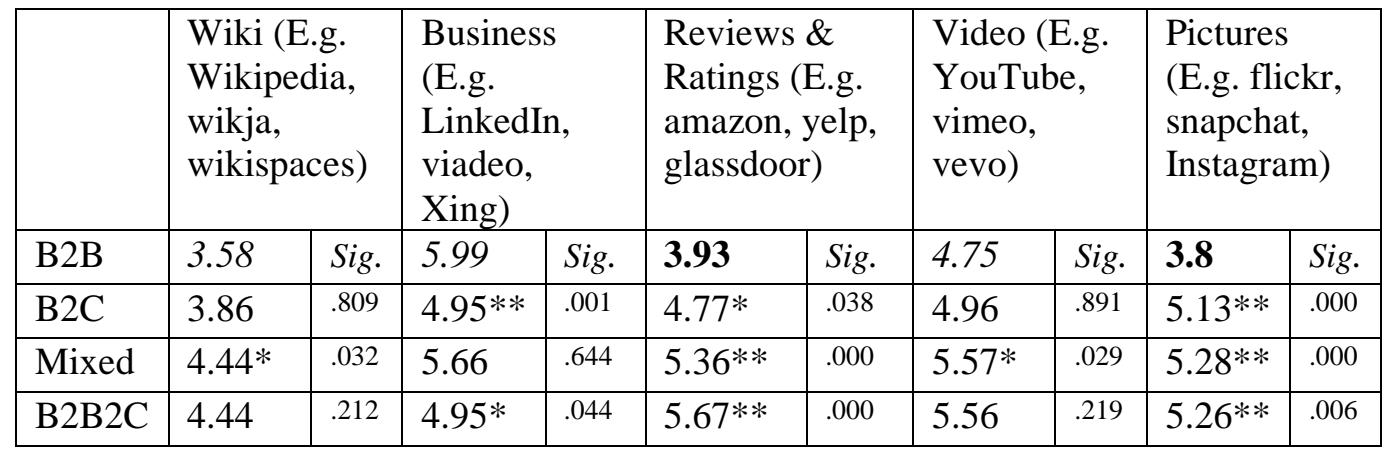

\begin{tabular}{|l|l|l|l|l|l|l|}
\hline & \multicolumn{2}{l|}{$\begin{array}{l}\text { Location } \\
\text { (E.g. } \\
\text { foursquare, } \\
\text { sonar, banjo) }\end{array}$} & $\begin{array}{l}\text { Content } \\
\text { marketing } \\
\text { (E.g. } \\
\text { Outbrain, } \\
\text { Taboola) }\end{array}$ & \multicolumn{2}{l|}{$\begin{array}{l}\text { Enterprise } \\
\text { (E.g. yammer, } \\
\text { chatter, tibbr) }\end{array}$} \\
\hline B2B & 3.31 & Sig. & 3.53 & Sig. & 3.48 & Sig. \\
\hline B2C & 3.72 & .556 & 3.6 & .996 & 3.43 & .999 \\
\hline Mixed & $4.34^{* *}$ & .006 & $4.45^{*}$ & .022 & 4.2 & .107 \\
\hline B2B2C & 3.86 & .603 & 4.57 & .106 & 4.07 & .559 \\
\hline
\end{tabular}




\section{Table 4: Customer orientated usage of social media}

How important is social media in managing the following activities?

$(1=$ not at all important, $7=$ extremely important $)$

\begin{tabular}{|c|c|c|c|c|c|c|c|c|c|c|c|c|}
\hline & \multicolumn{12}{|c|}{ Relationship Orientated Usage } \\
\hline & \multicolumn{2}{|c|}{$\begin{array}{l}\text { Sharing } \\
\text { recommend } \\
\text { ations }\end{array}$} & \multicolumn{2}{|l|}{ Selling } & \multicolumn{2}{|c|}{$\begin{array}{l}\text { Relationship } \\
\text { building }\end{array}$} & \multicolumn{2}{|c|}{$\begin{array}{l}\text { Providing } \\
\text { customer } \\
\text { service }\end{array}$} & \multicolumn{2}{|c|}{$\begin{array}{l}\text { Commu. with } \\
\text { current } \\
\text { stakeholders / } \\
\text { customers }\end{array}$} & \multicolumn{2}{|c|}{$\begin{array}{l}\text { Providing } \\
\text { product } \\
\text { information/ } \\
\text { specification }\end{array}$} \\
\hline $\mathrm{B} 2 \mathrm{~B}$ & 4.75 & & 4.74 & & 4.94 & & 4.39 & & 4.73 & & 4.67 & \\
\hline B2C & 5.15 & .131 & 5.11 & .242 & 5.3 & .235 & $5.16^{* *}$ & .001 & 5.05 & .399 & $5.11 *$ & .046 \\
\hline Mixed & 5.12 & .182 & $5.37 * *$ & .008 & $5.48 *$ & .200 & $5.42 * *$ & .000 & $5.34 *$ & .015 & $5.3^{* *}$ & .004 \\
\hline B2B2C & 5.33 & .125 & 5.19 & .386 & $5.79 * *$ & .008 & $5.7 * *$ & .000 & 5.19 & 390 & $5.49 *$ & .012 \\
\hline
\end{tabular}

\begin{tabular}{|l|c|c|c|c|c|c|c|c|c|c|}
\hline & \multicolumn{10}{|c|}{ Acquisition Orientated Usage } \\
\cline { 2 - 12 } & $\begin{array}{l}\text { Corporate } \\
\text { branding }\end{array}$ & $\begin{array}{l}\text { Building } \\
\text { corporate } \\
\text { identity }\end{array}$ & $\begin{array}{l}\text { Raising } \\
\text { awareness in } \\
\text { general }\end{array}$ & $\begin{array}{l}\text { Thought } \\
\text { leadership } \\
\text { (company } \\
\text { reputation) }\end{array}$ & \multicolumn{2}{l}{$\begin{array}{l}\text { Attracting new } \\
\text { customers }\end{array}$} \\
\hline B2B & 5.07 & & 5.06 & & 5.38 & & 5.12 & & 4.91 & \\
\hline B2C & 5.28 & .678 & 5.28 & .634 & 5.42 & .993 & 4.78 & .254 & 5.19 & .461 \\
\hline Mixed & $5.52 *$ & .048 & $5.56^{*}$ & .041 & 5.46 & .959 & 5.19 & .982 & $5.53^{* *}$ & .008 \\
\hline B2B2C & 5.28 & .851 & 5.47 & .428 & 5.7 & .562 & 5.28 & .934 & $5.7 *$ & .023 \\
\hline
\end{tabular}




\section{Table 5: Perceived Effectiveness of SMM}

$(1=$ strongly disagree, $7=$ strongly agree $)$

\begin{tabular}{|l|c|c|l|l|l|l|}
\hline & & $\begin{array}{l}\text { If used } \\
\text { correctly do } \\
\text { you agree } \\
\text { that social } \\
\text { In your } \\
\text { company is } \\
\text { social media } \\
\text { be a } \\
\text { an effective } \\
\text { marketing } \\
\text { shannel? }\end{array}$ & $\begin{array}{l}\text { lacessful } \\
\text { marketing } \\
\text { channel? }\end{array}$ & $\begin{array}{l}\text { lo you agree } \\
\text { that social } \\
\text { media is a } \\
\text { valuable } \\
\text { channel when } \\
\text { building } \\
\text { relationships? }\end{array}$ \\
\hline B2B & $\mathbf{3 . 9 3}$ & Sig. & 4.66 & Sig. & 4.47 & Sig. \\
\hline B2C & $4.45^{*}$ & .011 & 4.92 & .104 & 4.79 & .168 \\
\hline Mixed & $4.65^{* *}$ & .000 & $5.08^{* *}$ & .005 & $4.95 *$ & .011 \\
\hline B2B2C & $4.6^{*}$ & .030 & 4.93 & .362 & 4.84 & .339 \\
\hline
\end{tabular}


Table 6: Cross Loadings \& Reliability

\begin{tabular}{|c|c|c|c|c|c|c|}
\hline & AO & RO & DD & PE & $\alpha$ & $\mathbf{C R}$ \\
\hline Attracting new customers & 0.814 & 0.693 & 0.336 & 0.529 & \multirow[t]{6}{*}{0.892} & \multirow[t]{6}{*}{0.917} \\
\hline Building corporate identity & 0.842 & 0.676 & 0.341 & 0.388 & & \\
\hline Corporate branding & 0.810 & 0.637 & 0.345 & 0.374 & & \\
\hline Raising awareness in general & 0.849 & 0.628 & 0.359 & 0.424 & & \\
\hline Providing product information & 0.796 & 0.711 & 0.291 & 0.392 & & \\
\hline Thought leadership / reputation & 0.717 & 0.626 & 0.330 & 0.282 & & \\
\hline Sharing recommendations & 0.675 & 0.791 & 0.355 & 0.383 & \multirow[t]{5}{*}{0.867} & \multirow[t]{5}{*}{0.903} \\
\hline Providing customer service & 0.638 & 0.818 & 0.326 & 0.395 & & \\
\hline Communicating with customers & 0.601 & 0.807 & 0.323 & 0.351 & & \\
\hline Selling & 0.651 & 0.791 & 0.300 & 0.374 & & \\
\hline Relationship Building & 0.729 & 0.827 & 0.381 & 0.504 & & \\
\hline SEO & 0.263 & 0.297 & 0.743 & 0.313 & \multirow[t]{4}{*}{0.745} & \multirow[t]{4}{*}{0.836} \\
\hline Web PR & 0.308 & 0.253 & 0.710 & 0.296 & & \\
\hline Online broadcasting & 0.267 & 0.317 & 0.712 & 0.318 & & \\
\hline Social media channels & 0.380 & 0.373 & 0.827 & 0.554 & & \\
\hline Effective & 0.424 & 0.452 & 0.526 & 0.836 & \multirow[t]{3}{*}{0.810} & \multirow[t]{3}{*}{0.887} \\
\hline Successful & 0.434 & 0.392 & 0.408 & 0.877 & & \\
\hline Valuable & 0.425 & 0.438 & 0.375 & 0.840 & & \\
\hline
\end{tabular}


Table 7: Average Variance Extracted compared to Inter-construct Correlations

\begin{tabular}{|l|l|c|c|c|c|}
\hline & & $\mathbf{1}$ & $\mathbf{2}$ & $\mathbf{3}$ & $\mathbf{4}$ \\
\hline $\mathbf{1}$ & Acquisition Orientation_ & $\mathbf{0 . 8 0 6}$ & & & \\
\hline $\mathbf{2}$ & Digital Channel Dominance_ & 0.414 & $\mathbf{0 . 7 4 9}$ & & \\
\hline $\mathbf{3}$ & Perceived Effectiveness of SMM & 0.503 & 0.520 & $\mathbf{0 . 8 5 1}$ & \\
\hline $\mathbf{4}$ & Relationship Orientation_ & 0.821 & 0.420 & 0.504 & $\mathbf{0 . 8 0 7}$ \\
\hline
\end{tabular}

Average Variance Extracted (AVE) shown in diagonal. Bi-Variate Correlations shown below. 
Table 8: Path Level Co-efficients

\begin{tabular}{|l|c|c|c|c|c|c|c|c|}
\cline { 2 - 9 } \multicolumn{1}{c|}{} & \multicolumn{2}{c|}{ B2B } & \multicolumn{2}{c|}{ B2C } & \multicolumn{2}{c|}{ B2B\&B2C } & \multicolumn{2}{c|}{ B2B2C } \\
\hline Direct Effects & $\beta$ & $p$ val & $\beta$ & $p$ val & $\beta$ & $p$ val & $\beta$ & $p$ val \\
\hline AO > DCD & 0.252 & 0.173 & 0.079 & 0.582 & 0.351 & 0.004 & 0.352 & 0.071 \\
\hline AO > PE & 0.105 & 0.426 & 0.251 & 0.027 & 0.269 & 0.052 & 0.458 & 0.075 \\
\hline DCD > PE & 0.461 & 0.000 & 0.304 & 0.000 & 0.355 & 0.000 & 0.182 & 0.273 \\
\hline RO > DCD & 0.255 & 0.154 & 0.356 & 0.013 & 0.080 & 0.464 & 0.160 & 0.452 \\
\hline RO > PE & 0.255 & 0.080 & 0.132 & 0.283 & 0.113 & 0.401 & 0.049 & 0.844 \\
\hline
\end{tabular}

\begin{tabular}{|l|c|c|c|c|c|c|c|c|}
\cline { 2 - 9 } \multicolumn{1}{c|}{} & \multicolumn{2}{c|}{ B2B } & \multicolumn{2}{c|}{ B2C } & \multicolumn{2}{c|}{ B2B\&B2C } & \multicolumn{2}{c|}{ B2B2C } \\
\hline Total Effects (Digital Channels) & $\beta$ & $p$ val & $\beta$ & $p$ val & $\beta$ & $p$ val & $\beta$ & $p$ val \\
\hline AO > PE & 0.222 & 0.095 & 0.275 & 0.022 & 0.393 & 0.004 & 0.522 & 0.022 \\
\hline RO > PE & 0.372 & 0.014 & 0.240 & 0.063 & 0.141 & 0.266 & 0.079 & 0.734 \\
\hline
\end{tabular}

Key: AO - Acquisition Orientation; DCD - Digital Channel Dominance; PE - Perceived Effectiveness of SMM; RO - Relationship Orientation 